Metotreksat iliş̧kili Pansitopeni ve Mukokütanöz Toksisite

\title{
Methotrexate-Induced Pancytopenia and Mucocutaneous Toxicity
}

Ceren Erdoğan Eroğlư ${ }^{1}$, Esra Terzi Demirsoy ${ }^{2}$

${ }^{1}$ Sağlık Bilimleri Üniversitesi, Kocaeli Derince Sağlık Uygulama ve Araştırma Merkezi, İç Hastalıkları Kliniği, Kocaeli, Türkiye

${ }^{2}$ Sağlık Bilimleri Üniversitesi, Kocaeli Derince Sağlık Uygulama ve Araştırma Merkezi, Hematoloji Kliniği, Kocaeli, Türkiye

\begin{abstract}
$\ddot{O} Z$
Metotreksat onkolojik, romatolojik ve dermatolojik hastaliklar gibi çeşitli hastalıkların tedavisinde uzun yıllardır yaygın olarak kullanılmaktadır. Metotreksatın düşük doz kullanımı, nadiren kemik iliği supresyonu, mukokutanöz toksisite, hepatotoksisite, pulmoner fibrozis, böbrek yetmezliği gibi ciddi yan etkilere neden olabilir. Yaş, eşlik eden hastalıklar, proton pompa inhibitörü ve non-steroid anti-enflamatuar ilaçlar, metotreksatın haftalık yerine günlük kullanımı gibi çeşitli faktörler metotreksat toksisitesinin ortaya çıkmasını kolaylaştırmaktadir. $\quad B u$ olgu sunumlarında kliniğimize pansitopeni ile başvuran olgulardan hareketle metotreksat toksisitesine yaklaşım ele alınacaktır.
\end{abstract}

Anahtar Kelimeler: metotreksat, pansitopeni, mukokutanöz toksisite

\section{ABSTRACT}

Methotrexate has been widely used for many years in the treatment of variety of diseases including neoplastic, rheumatic and dermatological diseases. However, the use of low dose methotrexate rarely may cause side effect, such as bone marrow suppressions, mucocutaneous toxicity, hepatotoxicity, pulmonary fibrosis, renal dysfunction. Various factors facilitate the emergence of methotrexate toxicity; such as age, concomitant diseases, use of proton pump inhibitors and non-steroidal anti-inflammatory drugs, daily use of methotrexate instead of weekly. In these case reports; the approach to methotrexate toxicity will be discussed with reference to our patients with pancytopenia.

Keywords: methotrexate, pancytopenia, mucocutaneous toxicity 


\section{GíRiş}

Metotreksat (MTX) onkolojik, romatolojik ve dermatolojik hastalıklarda yaygın olarak kullanılan; dihidrofolat redüktaz enzimini yarışmalı olarak inhibe ederek DNA sentezini bozan antimetabolit bir ajandır (1). MTX'in DNA üzerindeki bu etkisi nedeniyle hizlı hücre döngüsüne sahip kemik iliği, gastrointestinal sistem, mukokütanöz (deri-mukozal) gibi dokular üzerinde yan etkilere neden olabilmektedir. MTX, düşük doz (maksimum 25mg/hafta) kullanımlarında nispeten güvenilir bir ajandır. Ancak daha nadir olmakla birlikte MTX'in düşük dozlarına bağlı yan etkiler de gözlenebilmektedir (2). $\mathrm{Bu}$ olgu sunumlarında romatoid artrit tanis1 nedeniyle düşük doz MTX kullanan iki hastada gelişen pansitopenin tartışılması amaçlanmıştır.

\section{OLGU 1}

46 yaşında erkek hasta son 10 gündür el ve el bileklerinde ortaya çıkan cilt lezyonları nedeniyle dış merkeze başvurmuş. Dış merkezde yapılan tetkiklerinde pansitopeni saptanması üzerine hematoloji polikliniğimize yönlendirilmiş. 3 senedir bipolar bozukluk nedeniyle lityum tedavisi alan hasta; 2 senedir romatoid artrit nedeniyle düşük doz MTX ve oral folik asit tedavisi almaktaydı. Hastanın en son 1 ay önce Romatoloji poliklinik kontrolüne giderek almakta olduğu MTX dozu haftada 4 tablet (10 mg/hafta) olacak şekilde düzenlenmiş. Bipolar bozukluğu nedeniyle özellikle son 20 gündür sosyal iletişiminin azalmasından dolayı hastanın tam olarak ne kadar MTX aldığı tespit edilemedi. Elindeki kutudaki MTX tablet sayısı sayılarak hastanın 20 gün içinde kümülatif olarak MTX dozunun 75-80 mg olduğu düşünüldü. Fizik muayenesinde deri, gövde ve ekstremitelerde yer yer nekrotik krutlu ağrilı ülsere plaklar (Resim-1,2,3,4) ve oral mukozayla dudaklarda yer yer nekrotik krutlu, ağrilı ülserler (Resim-5) saptandi.
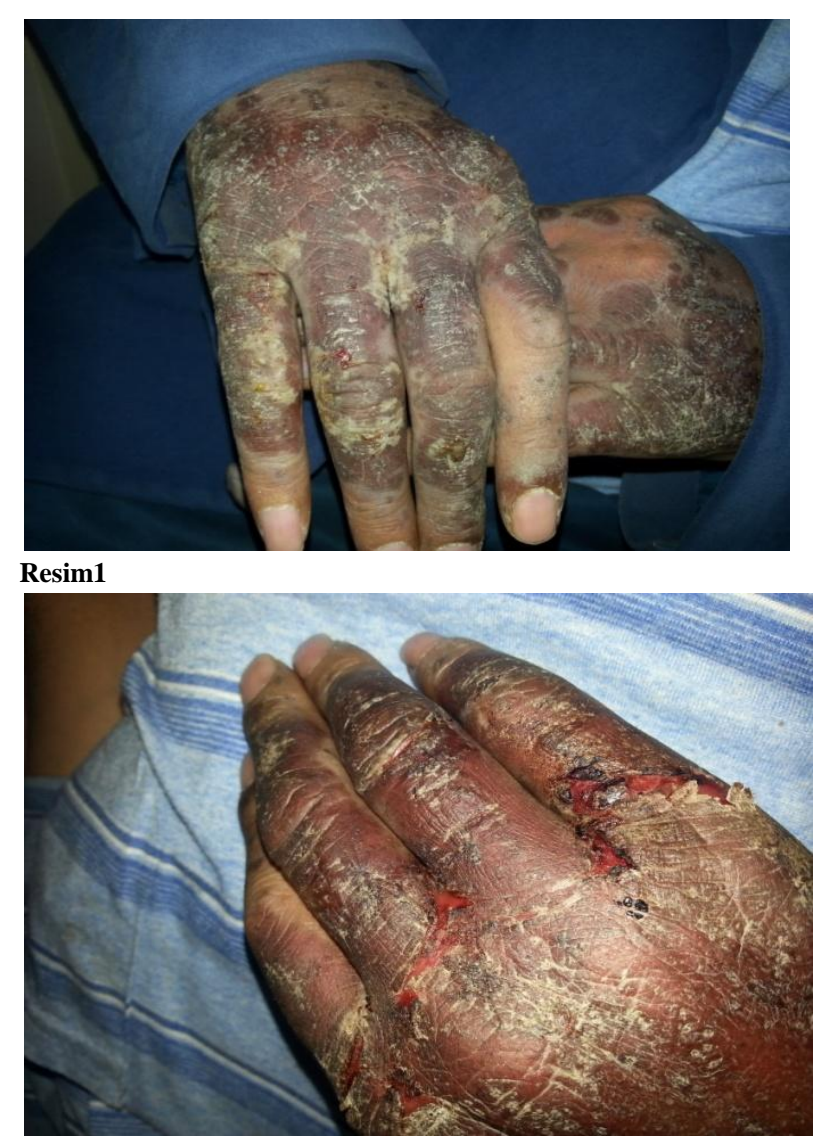

Resim 2

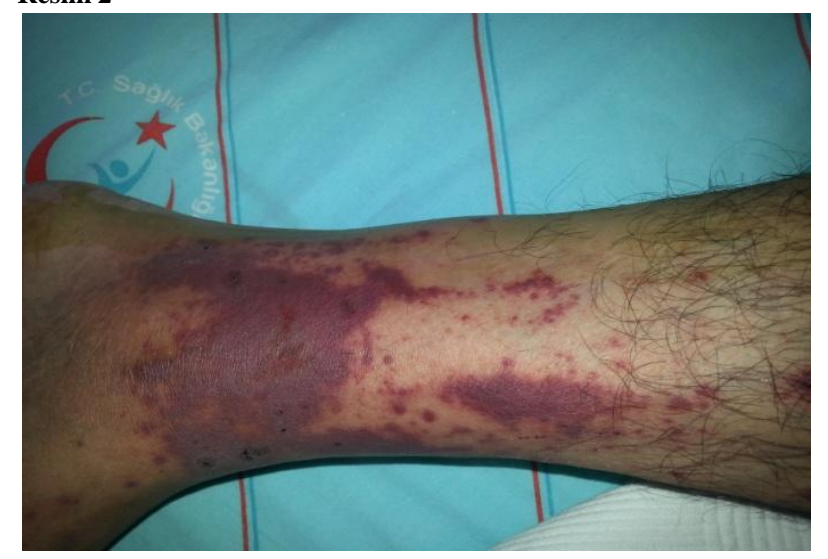

Resim 3

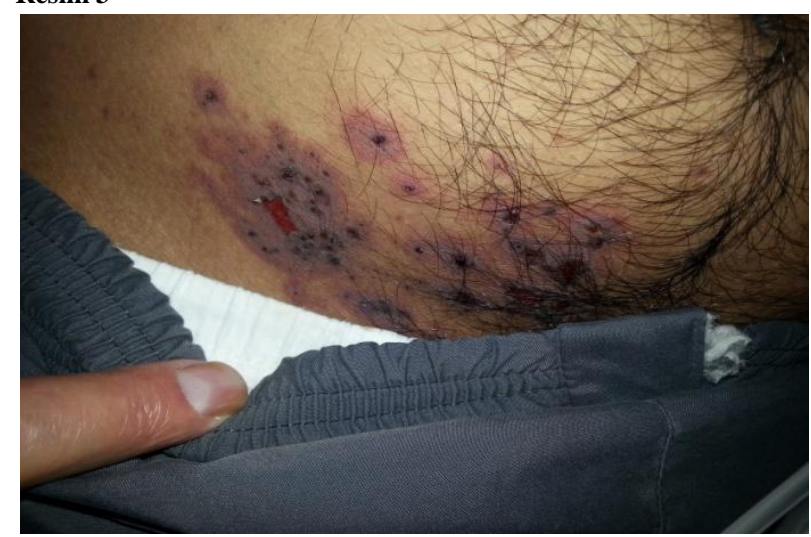

$\operatorname{Resim} 4$ 


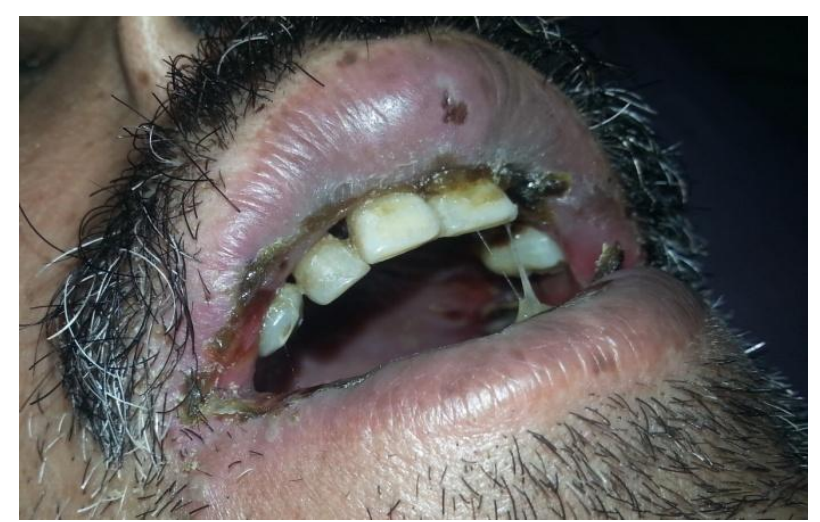

Resim 5

Kan basınc1 130/80 mmHg, ateş $38,7^{\circ}, \mathrm{Nab}$ ız 90 vuru/dk, oksijen saturasyonu \%97 saptand1. Diğer sistem muayenelerinde patoloji saptanmadi. Laboratuvar tetkiklerinde hemoglobin 10,7 g/dl, hematokrit \%33,1, MCV 95,3 fl, lökosit sayıs1 0,7 x $10^{3} / \mathrm{mm}^{3}$, nötrofil sayıs1 $0,3 \times 10^{3} / \mathrm{mm}^{3}$, trombosit say1s1 $13,8 \times 10^{3} / \mathrm{mm}^{3}$, CRP $>305 \mathrm{mg} / \mathrm{dl}$, saptand1. Vitamin B12, folik asit, ferritin düzeyleri, tiroid fonksiyon testleri ve diğer biyokimyasal parametreleri normal bulundu. $\mathrm{HBsAg}$, anti $\mathrm{HCV}$, anti HIV, Brusella aglütinasyon negatif saptandi. Yapılan periferik yaymasında; eritrositler morfolojik olarak makrositer görünümdeydi. Lökosit ve nötrofil sayısında azalma saptandı. Trombositler tekli, ortalama 30-40 bin civarında sayıldı. Atipik hücre görülmedi.

Hasta ön planda akut metotraksat toksisitesine bağlı pansitopeni olarak değerlendirildi. Febril nötropeni olarak değerlendirilen hastaya piperasilin+tazobaktam $4 \times 4,5$ gr ve oral kandidiyazis için flukonazol $800 \mathrm{mg} /$ gün yükleme sonrasında $400 \mathrm{mg} /$ gün idame tedavisi başlandı. GCSF (granülosit koloni uyarıcı faktör) tedavisi 48 MIU olarak başlandı. Metotreksata bağlı ciddi kemik iliği ve mukokutanöz toksisitesi için intravenöz folinik asit kurtarma tedavisi planland1. Hastaya intravenöz folinik asit $50 \mathrm{mg} 4 \times 1,3$ gün uyguland1. Günlük hemogram takibi yapılarak trombosit süspansiyonu replasmanı yapıldı. Yatışının 14. gününde sistemik antibiyoterapisi tamamlanan hastanın kliniğinin ve kan değerlerinin düzelmesi üzerine taburcu edildi (Tablo 1).

\section{OLGU 2}

54 yaşında kadın hasta bir haftadır devam eden halsizlik, ishal, ağız ve dudakta yaygın yaralar nedeniyle başvurdu. 3 senedir romatoid artrit tanısı olan hastanın tedavisi kolsişin $2 \mathrm{x} 1$, prednizolon 5 mg 1x1, MTX haftalık $10 \mathrm{mg}$ olarak tedavisi planlanmış. Hasta aynı zamanda ağrıları nedeniyle s1k non-steroid anti-inflamatuar ilaç ve proton pompa inhibitörü kullanmaktaydı. Sorgulandığında hastanın romatoid artrit için uzun zamandır kontrole gitmediği ve düzenli ilaç kullanımı olmadığı anlaşıldı. Ancak son 1 aydır eklem şikayetleri artan hasta MTX'i günlük 1 tablet (2,5mg) şeklinde almış. Fizik muayenesinde ağız içerisinde ve dudak çevresinde ağrllı aftöz lezyonlar mevcuttu. Hastanın laboratuvar tetkiklerinde hemoglobin $9 \mathrm{~g} / \mathrm{dl}$, hematokrit \%27,3, MCV $114 \mathrm{fl}$, lökosit sayıs $2,5 \times 10^{3} / \mathrm{mm}^{3}$, nötrofil say1s1 $0,7 \times 10^{3} / \mathrm{mm}^{3}$ ve trombosit sayıs $26 \mathrm{x}$ $10^{3} / \mathrm{mm}^{3}$ olarak saptanıp servise yatışı yapıldı. Yapılan tetkiklerinde CRP 23,7 mg/dl, $\mathrm{HBsAg}$, anti HCV, anti HIV negatif saptand. Diğer biyokimyasal parametreleri normaldi. Periferik yaymasinda eritrosit morfolojisi makrositer görünümdeydi. Atipik hücre görülmedi. Trombositler tekli, ortalama 30 bin civarında sayıldı. Gaita mikroskopisinde eritrosit lökosit görülmedi. Gaita kültüründe üreme olmadı.

Hasta ön planda akut metotraksat toksisitesi olarak değerlendirildi. Oral folik asit $1 \times 1$, intravenöz hidrasyon başlandı. 3 gün G-CSF tedavisi ile nötrofillerinde yükselme görüldü. Hastanın takiplerinde ateşi olmaması ve genel durumunun her gün iyiye gitmesi nedeniyle oral folik asit 1x1 tedaviye devam edildi. Hasta yatışının 7.gününde kliniği ve kan değerlerinin düzelmesi ile taburcu edildi (Tablo 1).

Tablo 1. Hematolojik parametreler

\begin{tabular}{|l|l|l|l|l|l|l|l|l|}
\hline & \multicolumn{9}{|c|}{ OLGU 1 } & \multicolumn{2}{c|}{ OLGU 2 } \\
\cline { 2 - 9 } & $1 . G U ̈ N$ & $7 . G U ̈ N$ & $10 . G U ̈ N$ & $12 . G U ̈ N$ & $14 . G U ̈ N$ & $1 . G U ̈ N$ & $4 . G U ̈ N$ \\
\hline Lökosit & 700 & 2400 & 4100 & 5700 & 7600 & 2300 & $7 . G U ̈ N$ \\
\hline Lentrofil & 0 & 200 & 1200 & 2600 & 2100 & 800 & 1100 \\
\hline Hemogit & 600 & 1000 & 1500 & 2400 & 3300 & 800 & 1200 \\
\hline Hemotokrit & 10,7 & 12,2 & 12 & 13,1 & 13 & 9,6 & 9,1 \\
\hline Trombosit & 33 & 37,2 & 36,8 & 40,1 & 40 & 29,8 & 1500 \\
\hline
\end{tabular}




\section{TARTIŞMA}

1940’11 yıllarda geliştirilen MTX, ilk olarak yüksek dozda (>1000 mg tek doz) lösemi tedavisinde kullanılmaya başlanmıştır. Ancak ilerleyen y1llarda daha düşük dozlarda (15-25 mg/hafta) inflamatuar artritlerde kullanıma girmiştir. MTXın romatoid artritte kullanımı ilk kez 1951 yılında dökümente edilmiştir. Son 25-30 y1l içerisinde yetişkin romatoid artrit tedavisinde standart bir yaklaşım haline gelmeye başlamıştır (3). MTX kolay tolere edilebilir olması, etkililiği ve güvenilirliği nedeniyle romatoid artrit tedavisinin temel ilacı olmuştur ve herhangi bir kontraendikasyonu olmadıkça başlangıç tedavisi olarak kullanılması önerilmektedir (4).

Folik asitin yapısal analoğu olan MTX, dihidrofolat redüktaz enziminin katalitik bölgesine bağlanarak timidilat, pürin nükleotidleri, serin ve metionin sentezini durdurarak DNA, RNA ve protein sentezini inhibe eder. MTX'ın pürin baz metabolizmasındaki birkaç enzimi üzerindeki inhibitör etkisiyle adenozin birikimi yoluyla teröpatik etkisinin oluştuğu düşünülmektedir. $\mathrm{Bu}$ etkisini lenfosit ve makrofajların fonksiyonlarını, polimorfonükleer hücrelerin kemotaksisini, immunglobin ve proinflamatuar sitokinlerin üretimini azaltarak gösterir $(5,6)$.

MTX, hücre döngüsünün $S$ fazında DNA ve RNA sentezini engelleyerek antiproliferatif etki gösterir (5). Bu etki özellikle hızlı hücre döngüsüne sahip hematopoetik, gastrointestinal, kutanöz hücreler olmak üzere diğer organ ve sistemlerin normal metabolizması üzerinde de etki göstererek yan etkilere neden olabilmektedir $(5,7)$. MTX; kullanıldığ1 hastalığa göre yüksek (>500mg/m2), orta $(50-500 \mathrm{mg} / \mathrm{m} 2)$, düşük doz $(50 \mathrm{mg} / \mathrm{m} 2)$ tedavi rejimlerinde kullanılmaktadır. Yan etkiler daha sık yüksek doz kullanımda görülse de daha nadir olarak düşük doz kullanımda da gözlenebilmektedir (2). Düşük doz MTX kullanımına bağlı yan etkiler; doz bağımlı etki (A), idiyosenkratik etki (B), kümülatif doza bağl1 etki (C) ve ilacın bırakılmasından sonra oluşan gecikmiş etki (D) olmak üzere dört kategori halinde sınıflandırılmıştır. Kategori A ve B mukokutanöz, gastrointestinal toksisite ve pansitopeniyi kapsar. Katagori C de hepatik fibrozis ve pulmoner toksisite gözlenirken kategori D teratojeniteyi içerir (7). Düşük doz MTX kullanımı genellikle iyi tolere edilse de ilk 24-48 saat içerisinde gastrointestinal semptomlar (bulant1, kusma, ishal, stomatit), dermatolojik semptomlar (malar rash, alopesi), hafif santral sinir sistemi semptomları (baş ağrısı, konsatrasyon güçlügü̈) gibi yaşamı tehdit etmeyen ve tedavinin kesilmesini gerektirmeyen yan etkiler gözlenebilir (8). Daha nadir olarak major santral sinir sistemi bulguları, mukozit, kutanöz ülserler, myelosupresyon, hepatotoksisite, pulmoner bulgular gözlenebilir ve bu bulgular tedavinin kesilmesini gerektirecek kadar şiddetli bir klinikle karşımıza gelebilir $(7,8)$. İlk olgunun 20 gün içerisinde toplam 75-80 mg MTX kullandığ1 düşünülmekte olup olguda daha nadir görülen pansitopeni, mukozit ve kutanöz ülserler mevcuttu. İkinci olgumuz günlük 2,5 mg MTX kullanmaktaydı pansitopeni, mukozit ve ön planda MTX ile ilişkili olduğu düşündüren ishal şikayeti vard. Yani kategori A ve B yi içeren akut toksisite bulguları mevcuttu.

Düşük doz MTX ilişkili mukokutanöz toksisite görülme oranı oldukça düşüktür. Bir çalışmada 1951 ile 1996 yılları arasında 66 hasta olduğu bildirilmiştir $(7,9)$. Bir diğer çalışmada mukokutanöz toksisite prevelansının $\% 8,9$ olduğu belirtilmiştir. Mukokutanöz toksisite görülen hastaların yaklaşık \%4 ünde tedavinin kesilmesi gerekmiş ve birkaç ay sonra toksisite bulguları gerilemiştir. Stomatit ve oral ülserasyonların görülme sıklığının \%14 olduğu tahmin edilmekte olup bu hastaların \%3'ünde tedavinin kesilmesi gerekmiştir. Oral mukozada oluşan bu lezyonlar; hastanın yaşam kalitesini ciddi düzeyde bozup, devam eden tedaviye uyumunu da azaltabilmektedir $(10,11)$.

Düşük doz MTX ilişkili hematolojik toksisiteler tek veya iki hücre serisinin etkilenmesi veya pansitopeni olarak karşımıza çıkabilmektedir. Bir çalışmada romatoid artrit nedeniyle 3 y1l boyunca MTX tedavisi alan hastaların \%5,2 sinde tek hücre serisinin etkilendiği sitopeni saptanmıştır. Hafif düzeyde lökopeni ve trombositopeni \%12'ye kadar oranlarda görülebilmektedir. Pansitopeni insidansının $\% 0,96-1,4 \quad$ arasında olduğu düşünülmektedir. Literatürde pansitopeninin mortal seyrettiği vakalar olmakla birlikte miyelotoksisite vakaların $1 / 4$ ünde MTX alımının ilk 1 ayında öncelikle makrositoz olarak meydana gelip genellikle ilaca verilen 2 haftalık aradan 
sonra düzelmektedir. Sitopeni nedeniyle MTX'1n kalıcı olarak kesildiği vakalar klinik pratikte nadirdir (\%0-5,9) (10).

MTX ilişkili pansitopeni doz bağımlı olarak veya daha nadir olmak üzere idiosenkratik yan etkiyle tedavinin ilk 10 gününde gözlenir. Mukozit ise genellikle ilacın alımından sonraki ilk 7 gün içerisinde gerçekleşir. MTX in mukozal epitelyum hücrelerinde kemik iliğinden daha yüksek oranda birikmesi nedeniyle mukozit gelişimi pansitopeniden önce olmaktadır (7). Mukozit gelişimi lökosit ve trombosit sayılarının düşeceğinin habercisi olabilmektedir (9).

MTX'e bağlı akut toksisite gelişmesinde bazı risk faktörleri kolaylaştırıcı rol oynamaktadır. En yaygın nedenler arasında haftalık tedavi yerine günlük tedavi almak gibi doz ayarında yapılan hatalar ve hastanın kullanmakta olduğu ek ilaçlardır. Bu ilaçlar arasında başta non-steroid anti-inflamatuar ilaçlar olmak üzere proton pompa inhibitörleri, penisilin, sulfonamid, tetrasiklin gibi antibiyotikler, diüretikler, salisilat, bazı antiepileptikler gibi pek çok ilaç bulunmaktadır. Diğer nedenler arasında ileri yaş $(>55)$, renal fonksiyonlarda yetersizlik, düşük albumin seviyesi, enfeksiyon, yüksek dozda alkol alımı, folik asit eksikliği yer almaktadır $(1,7)$. Kognitif fonksiyon bozukluğu olan, ek ilaç kullanımı çok olan veya yalnız yaşayan yaşlı hastaların, konuşma bozukluğu olan ve psikiyatrik tanısı olan hastaların MTX kullanımından kaçınılması gerektiği önerilmektedir (7). İlk olgu 3 yıldır bipolar bozukluk nedeniyle lityum tedavisi almasını gerektiren psikiyatrik hastalığ 1 vardı. Psikiyatrik hastalığı nedeniyle hastanın kendisinden ne kadar MTX kullandığına dair düzgün bir anamnez alınamadı. İkinci olgumuzda ise düzenli ilaç kullanımı olmadığı ve düzenli olarak kontrollerine gitmediği anlaşıldı. Aynı zamanda hastanın sık non-steroid anti-inflamatuar ilaç ve proton pompa inhibitörü kullanımı öyküsü vardı. Her iki olgumuzda da romatoid artrit nedeniyle kullanmakta olduğu MTX tedavisini hatalı olarak haftalık olarak değil günlük olarak aldığı tespit edildi.

Normalde MTX tedavisi alan hastalarda gastrointestinal ve hematolojik yan etkileri önlemek amaciyla folik asit takviyesi verilmektedir. Ancak bazı vakalarda ilk olgudaki gibi oral folik asit takviyesi almasına rağmen akut
MTX toksisitesini düşündürecek klinik gelişebilmektedir. Toksisite bulguları bazı vakalarda mortal seyredebilir. Erken tedavi mortaliteyi azaltmaktadır. MTX kesilmeli, renal atılımı artırmak amaciyla intravenöz hidrasyon desteği ve antidot olarak folinik asit verilmelidir $(7,9)$.

Sonuç olarak MTX kullanımına bağlı pansitopeni ve ciddi mukokutanöz yan etkiler düşük dozlarda da görülebilmektedir. MTX kullanan hastalarda bu yan etkilere karşı daha yakın takip edilmeli, eşlik eden hastalıkları nedeniyle beraberinde kullanmakta olduğu ilaçların yan etki görülme olasılığını artırabileceği unutulmamalıdır. İleri yaş, psikiyatrik hastalığı gibi ilaç uyumunun zor olacağı düşünülen veya düzenli kontrole gelemeyecek hastalarda MTX kullanımı tekrar gözden geçirilmelidir.

\section{KAYNAKLAR}

1. Demir FT, Tezcan Y, Türkoğlu Z, Başaran Ş: A case of Severe Low-dose Methotrexate-induced Toxicity. Med Bull Haseki. 2016; 54:252-254.

2. Arslan E, Özçelik F, Çakar M, Öztosun M, Demirbaş Ş, Sağlam K: Düşük Doz Oral Metotreksat Kullanımı ile Ortaya Çıkan Pansitopeni ve Deliryum Tablosu: Olgu Sunumu. Gülhane Tip Derg. 2014;56: 182-184.

3. Brown PM, Pratt AG, Isaacs JD: Mechanism of action of methotrexate in rheumatoid arthritis, and the search for biomarkers. Nat Rev Rheumatol. 2016 Dec;12(12):731-742.

4. Goodman SM, Cronstein BN, Bykerk VP: Outcomes Related to Methotrexate Dose and Route of Administration in Patients with Rheumatoid Arthritis: A Systematic Literature Review. Clin Exp Rheumatol. 2015; 33(2): 272-278.

5. Cipriani P, Ruscitti P, Carubbi F, Liakouli V, Giacomelli R: Methotrexate in rheumatoid arthritis: optimizing therapy among different formulations. Current and emerging paradigms. Clin Ther. 2014 Mar 1;36(3):427-35.

6. Cronstein BN: Low-Dose Methotrexate: A Mainstay in the Treatment of Rheumatoid Arthritis. Pharmacological Reviews. 2005; 57:163-172.

7. Yélamos O, Català A, Vilarrasa E, Roé E, Puig L: Acute Severe Methotrexate Toxicity in Patients with Psoriasis: A Case Series and Discussion. Dermatology. 2014; 229:306-309.

8. Kivity S, Zafrir Y, Loebstein R, Pauzner R, Mouallem M, Mayan H: Clinical characteristics and risk factors for low dose methotrexate toxicity: a cohort of 28 patients. Autoimmun Rev. 2014 Nov;13(11):1109-13. 
9. Yıldız B, Erdoğan H, Bulur I, Aslan A, Saraçoğlu Z: Kutanöz ülserler ile seyreden akut metotreksat toksisitesi. Osmangazi Journal of Medicine. 2016;38:74-77.

10. Romão VC, Lima A, Bernardes $M$, Canhão $H$, Fonseca JE: Three decades of low-dose methotrexate in rheumatoid arthritis: Can we predict toxicity? Immunol Res. 2014 Dec;60(2-3):289-310.

11. Demirkiran D, Kurt H, Yüksel M, Sari Y. Pancytopenia and Mucositis Encountered in the Early Stages of Methotrexate Treatment. Eur J Health Sci. 2017;3(1): XX. 